\title{
From Domestic to Public: Representation of Working Women in Damar Kurung Painting
}

\author{
Aniendya Christianna ${ }^{1, *}$, Acep Iwan Saidi², Riama Maslan Sihombing ${ }^{3}$ \\ ${ }^{1}$ Program Doktor FSRD Institut Teknologi Bandung, \& Universitas Kristen Petra Surabaya Indonesia \\ ${ }^{2}$ Program Doktor FSRD Institut Teknologi Bandung, Indonesia \\ ${ }^{3}$ Program Doktor FSRD Institut Teknologi Bandung, Indonesia \\ ${ }^{*}$ Corresponding author. Email: 37020004@mahasiswa.itb.ac.id
}

\begin{abstract}
Among the handicrafts of leather, brass, and plait in Gresik, there is the traditional Damar Kurung handicraft which is currently extinct. Damar Kurung is a traditional handicraft shaped like a rectangular lantern, decorated with paintings on the socio-cultural conditions of Gresik on each side. The Damar Kurung painting can be grouped into several themes, one of which is the theme of social activities which shows the economic activity of the Gresik population. Both male and female residents of Gresik participate in advancing the regional economy. This research is qualitative research with an interpretive descriptive approach, in which the data of Damar Kurung paintings are analyzed using Roland Barthes semiotics to reveal connotative meanings, denotation to the mythical level. Based on the analysis, the research results: (1) Javanese women's work is centered from within/the domestic area (family/household) to the public area. (2) Criticism of the myth of the Konco Wingking in the context of working Javanese women. (3) Javanese women who work always try to maintain the balance of the Jagad Gede and the Jagad Cilik as a form of devotion to God and fellow humans.
\end{abstract}

Keywords: Economy, Women, Damar Kurung, Traditional Art, and History

\section{INTRODUCTION}

During the Majapahit Kingdom (15th century) on the island of Java, there were four important port cities, namely Mojokerto, Surabaya, Tuban, and Gresik [13]. Gresik is an area located on the northern coast of Java Island that has played an important role in the history of the archipelago. This important role has even lasted long before the formation of the current Gresik Regency. This rapid development is supported by the topography where two main rivers flow, namely the Bengawan Solo and Lamong which flow into the Madura Strait. Geographically, Gresik has barren limestone soil and hard hills, not suitable for agriculture. However, Gresik developed rapidly into an international port because the communication and trade network at that time relied on the sea and rivers. This has encouraged the people of Gresik from the past to the present, to live with a livelihood as craftsmen, fishermen, and traders [15].
Sunan Giri is a role model for the Gresik community who encourages trade activities in line with religious activities [16]. As a result, the people of Gresik are known to this day for their tenacity in trading and entrepreneurship. Now entrepreneurship continues to grow and expand, not only in terms of cultivating fish ponds but also in other businesses, such as pottery, silver, gold, leather, sarongs, caps/ udheng, and mats.

Fish from ponds and processed natural products such as pepes milkfish, soft thorn milkfish, grilled milkfish, tuak/legen (traditional alcoholic beverage), crackers, shrimp paste, and various traditional snacks are trade commodities in Gresik [8]. In addition, there are also handicrafts made from leather, metal, brass, and woven pandanus leaves. Among the various variations of Gresik's natural commodities, there is also a Gresik-specific cultural commodity, namely Damar Kurung. 
Damar Kurung is a traditional craft in the form of lanterns. This lantern is made of paper with a bamboo frame. This paper serves as a protector to keep the fire burning [9]. Instead of making plain lanterns, the paper that wraps these lanterns is decorated with various colorful paintings, so that the glow of the light becomes more beautiful. The original Gresik artist who made Damar Kurung was named Sriati Masmundari (1904-2005). Masmundari was too old (84 years old) when she was active in producing Damar Kurung. Although illiterate, she has a sensitivity in capturing the events of everyday life which became the inspiration for Damar Kurung's painting. The painting that adorns the lanterns is inspired by the events that occurred around Gresik [2]. Because society is a mental unit that is built from everyday space and then becomes a reference for each member to digest the reality that comes in the social world. One of the inspirations for his paintings is the theme of the economy, such as scenes at the night market, milkfish market, and farming in the rice fields.

Traditionally, Javanese women are active. They are allowed to carry out economic activities outside the home by trading or working in the fields as men do. In contrast to the phenomenon experienced by Kartini (1879-1904) who had to undergo a period of seclusion when she was a teenager. During the seclusion period, Kartini was absolutely not allowed to leave the house, either to get an education or for economic activities. Kartini's experience is a consequence of women being part of the priyayi (noble) group. It is different with women from the underprivileged group. Women and men from lower classes have relatively equal power and bargaining position to work and earn wages [14].

By carefully observing the paintings in Damar Kurung, it can be understood the socio-cultural conditions that occurred in Gresik. Is it true that the Javanese woman depicted in Damar Kurung's paintings is only a konco wingking? What is the role of Javanese women depicted in Damar Kurung in an effort to advance the economy of their families and communities? What is the strategy of Javanese women in carrying out their dual roles in the domestic (household) and public (social) areas?

\subsection{Damar Kurung}

Damar Kurung is one of the arts from the east coast culture, especially in the Gresik Regency area. In a linguistic sense, 'Damar' means light (from a candle), and 'Kurung' means cover. Overall, Damar Kurung's terminology is a lamp with a hood (Koeshandari:
2009). Physically, Damar Kurung is like a chandelier or decorative lantern. The strength of Damar Kurung is in the painting that adorns the paper of his cage. Paintings with figurative and representative symbols depict the dynamics of Gresik people's life.

Based on Novan Effendy's explanation, one of the Damar Kurung conservationists from the Damar Kurung Institute said that this lantern tradition has existed since the classical Hindu-Buddhist era. At first it functioned as a lamp symbol for the lamp in the process of paying for the corpse. The lamp is used as a tool to illuminate the path of the soul to another life after death [3]. This artifact was further developed during the Giri Kingdom in the 4th century by Sunan Prapen. Because at that time, the influence of Islam had dominated, so Damar Kurung also acculturated. Since the time of Sunan Prapen, Damar Kurung is not only used during funeral rituals but also as a marker for the entry of the month of Ramadan every year.

Sriati Masmundari: maestro Damar Kurung is a woman who devotes her life to preserving Damar Kurung [11]. In 1987, Sriwati Masmundari for the first time held a solo exhibition at Bentara Budaya Jakarta. This appreciation has an impact on the transformation of Damar Kurung, from a three-dimensional form into a two-dimensional medium, using paper or canvas. Since Masmundari died in 2005, efforts to preserve Damar Kurung have started to slacken along with the dominance of electric lights. Many people interested on Masmundari's work, so that her works were sold and scattered, both domestically and abroad, without good documentation and archiving.

\subsection{Women's Role}

Women's studies that examine gender relations in a Western perspective, generally divide gender inequality that occurs in women into six categories, namely (1) marginalization or the process of economic impoverishment in women; (2) subordination or presumption of unimportance in political decisions; (3) stereotyping of women or through negative labeling; (4) violence against women, (5) disproportionate workload, longer and more workload (burden), and (6) socialization of the ideology of gender role values [4].

Stereotyping of women with domestic work is still the most frequently used way to perpetuate patriarchal ideology. Budiman said that domestic work was never considered a job [1]. Domestic work is considered not to make money in the economic dimension so that domestic work is not part of productive work. Therefore, women who work in the public sphere are constantly burdened with domestic responsibilities 
such as raising children, taking care of their husbands, cooking, preparing for family needs, and other domestic work. Women who choose to work in the public sector must do both things at once.

\section{METHOD}

This study seeks to accurately describe the characteristics of an individual, condition, phenomenon of a particular group or describe the relationship between one symptom and another based on visual data in Damar Kurung's painting. The method used is qualitative with a semiotic analysis approach of Roland Barthes to reveal the signs and meanings of the myth of visual image as the basis of the research. Roland Barthes' semiotics describes the meaning of signs with a first-level meaning system or denotation, and a second-level system or connotation. The absence of meaning between denotation and connotation occurs because of a myth.

The research steps to be carried out are as follows:

1. A search of Masmundari's Damar Kurung from 1970 to 1990 , through the Damar Kurung Institute and collectors.

2. Documenting Masmundari's Damar Kurung from 1970 to 1990 . At the same time collecting data through interviews with collectors and conservationists of Damar Kurung in Gresik.

3. Selecting and sorting Masmundari's Damar Kurung according to the chronology of its creation (from 1970 to 1990 ).

4. Observing and selecting the theme of Masmundari's Damar Kurung painting, within the scope of economic activity. Researchers act to interpret, interpret and understand the observed visual objects.

5. The results of the analysis of these signs and meanings are finally examined further in relation to the role of women in the economy and the sociocultural relations that lie behind them.

6. Conclusion

\section{RESULT AND DISCUSSIONS}

\subsection{The myth of Konco Wingking: The role of women from behind in the economy}

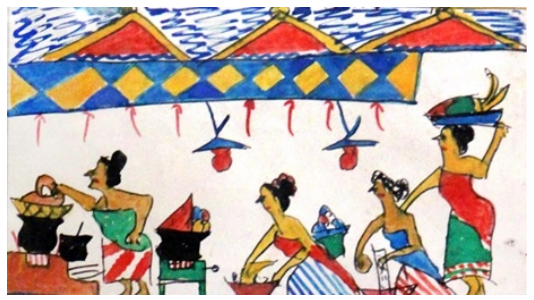

Figure 1 Cooking is one of the domestic activities for Javanese women.

Mythology is a product of social knowledge that comes from a social phenomenon and involves the whole community to believe it, spread it, take a position on that belief and then act on that position [7]. In a certain sense, mythological knowledge is contrary to scientific knowledge because the source of its formation and the process of spreading it follows the social currents of the society in which the mythology grows.

The myth of Konco Wingking in Javanese culture has been internalized in the mental structure of the Javanese. Wong lanang nang ngarep, wong wedok nang mburi (male in front, female behind), is often associated with material spaces: the front is public and the back is domestic. The domestic area includes the household area with all activities in it, such as cooking, raising children, serving husbands, cleaning the house, and other domestic activities (figure 1). In the social reality prevailing in Javanese society, the division of symbolic roles is maintained. The Javanese strictly adhere to and respect these differences. That domestic life is one way for Javanese people to learn to know their role and place. If the basis of the structure of the division of roles is complementarity, it can be concluded that for the Javanese world, the responsibilities of each group are built on the principle of difference, rather than the principle of equality.

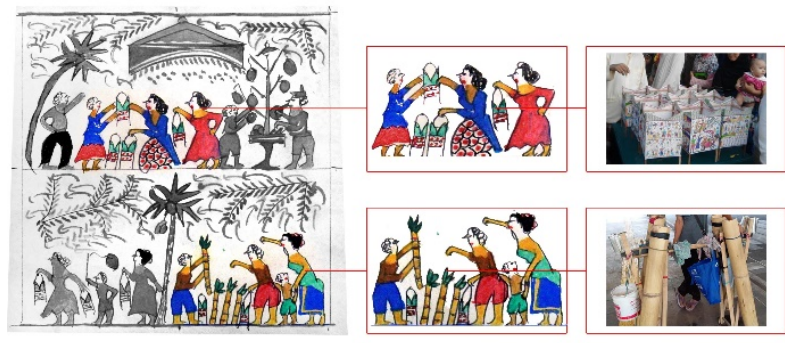

Figure 2 Legen and Damar Kurung are examples of commodities that are often traded in Gresik

Masmundari's Damar Kurung painting often depicts women's domestic activities, such as cooking, making batik, and taking care of children (to Posyandu). Masmundari does not seem to deny her role and position as a wife and mother. However, in 
other paintings, Masmundari also paints a lot about women's activities in the public sphere, especially trading activities. Gresik's typical commodities such as milkfish, pudak, legen, various traditional dishes/ cakes, batik and including Damar Kurung handicrafts can be seen in the painting with the theme Pasar Malam (Night Market) (figure 2). In paintings, women are shown not only as buyers but also as sellers. The various commodities that appear in Damar Kurung's paintings show that these commodities are not the product of the factory industry, but the work of women from within the household (domestic).

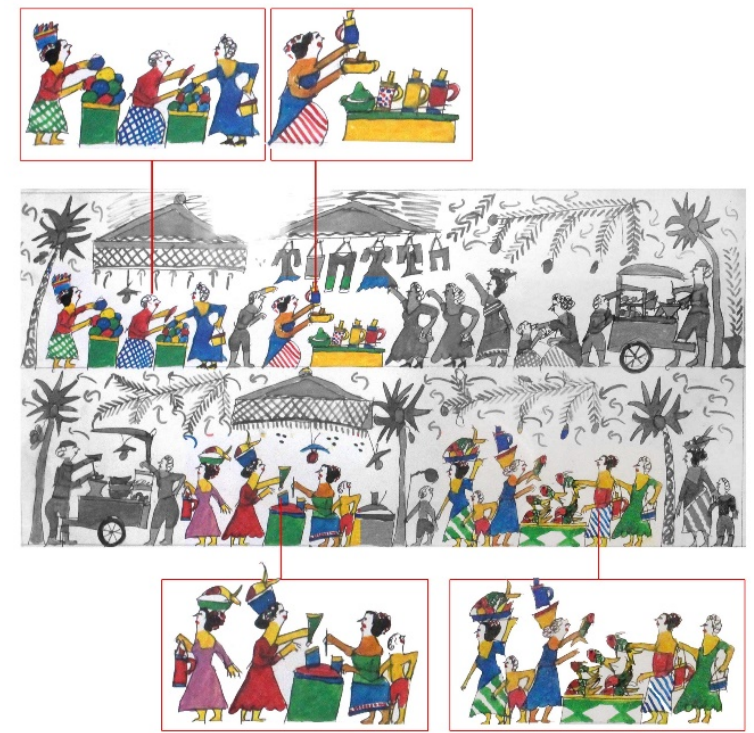

Figure 3 Working women in Damar Kurung's Paintings

The work of women in Damar Kurung's paintings as food makers, batik makers, craftsmen, selling fish, and trading in the market cannot be related to the idea of work and professional wages as in the factory and office industries in general (figure 3). Because women's work like this does not have a definite measurement of production time, does not require a detailed level of intelligence and skill competence, as well as there is no fixed size for the wages that will be received. So, working for Javanese women is not result-oriented, but focuses on the idea of actively working and building social networks in the community. The concept of sepi ing pamrih, rame ing gawe (not prioritizing one's own ego, but doing one's duty wholeheartedly) is the mental foundation of Javanese people about work. This moral basis encourages Javanese women to concentrate fully on their business and work, and not to be bothered by worries about the results (wages/money) later, so that the idea also contains a total active submission to God.
Koentjaraningrat and Geertz revealed that Javanese women have a big influence in domestic (household) affairs [10]. Similar to Denys Lombard, he also mentioned that women play an important role in Javanese life [12]. The role of women, even behind the scenes, remains powerful and becomes the axis of the growth of households and communities in which they are located [5]. Rogers adds that in the Javanese world, male domination is ultimately only an ideology. When faced with reality, this male domination becomes a myth. On the other hand, women's domination is real and practical domination in everyday life. Although women are considered to be in the back position (in the household), the impact of their role is large on the welfare of the family and society. So it appears that women perform their role as puppeteers who determine the storyline of the wayang they play.

In Javanese society, work is more meaningful as a representation of a social activity than a productive activity. When work is a social activity, mentally the thoughts to develop work representations are very varied. Women must be able and willing to do anything. Damar Kurung's painting shows that the center of informal economic activity in the household. In this sense, women's work activities in the social world are actually an extension of the household activity itself. At first, the concept of informal work like this was not considered as national income because of its informal nature and its character that did not allow it to be recognized as an economic structure of the production system. But at this time, the Indonesian economy has evolved and developed thanks to the informal sector like this with creative industry development programs that are entirely done from the household. Thus, it can be concluded that the impact of women's roles in the domestic sphere can be felt widely to the community (social).

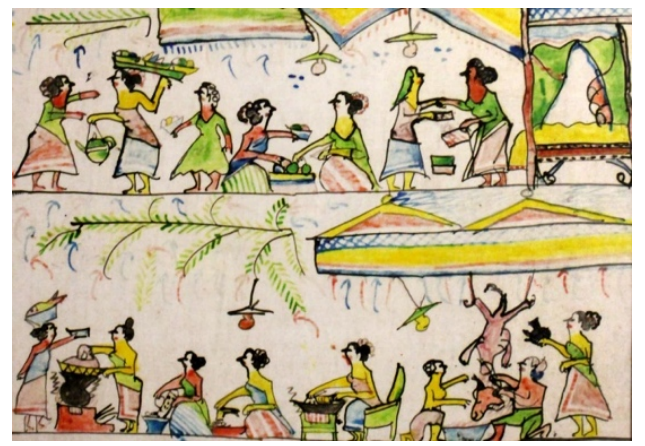

Figure 4 Women's activities not only indoors, but also outdoors

Masmundari's Damar Kurung painting shows women's activities not only outdoors (such as the 
market and the sea), but also indoors (as can be seen from the triangle-like roof of a house- at the top of the image plane) (figure 4). This shows that women's space for movement is in the household area (also). Javanese consciousness is manifested in the relationships that women build in everyday life with men in a space called the household. This space is the structure and building of social balance that determines the existence of Javanese society. The household is considered the main place of activity for Javanese women. The household is the main place for women to gain awareness of their position in the Javanese world, namely as wives as well as mothers and workers. Based on observations of visual data and social phenomena, it shows that household economic resources and community resources are fully under the responsibility of women.

In the household, women can take care of their husbands and take care of their children, as well as work to earn money, confirming that the household is not a structure that confines women. The household is not a separate world from the world where women develop social networks to expand their social space. Household affairs are not merely domestic spaces. The household is the link in the social chain of society. This means that the existence of Javanese women in the household is not possible except in connection with what is outside the home. The openness and flexibility of the household imply the active movement of women.

In this connection, there are rules that apply that women can carry out tasks in the social space if she succeeds in carrying out tasks starting from her own household. It is different from the Western world which considers that the household is a private and separate domestic area. On the contrary, in the Javanese world, the household is a domestic area that is not separated from the social sphere, it can even be said to be connected. For Javanese women, the household is not merely defined as a private space that separates the individual from the community. The household is a social space that slips into the domestic area, and vice versa: social space easily enters and slips as part of the household. In everyday life, the household remains the center that determines the entire structure of the worldview.

By working, Javanese women are in the rotational axis of the public sphere and the domestic sphere (household). Women can do whatever they want, as long as they don't abandon their household. Javanese women have the ability to continuously assimilate and interpret their daily life experiences within the framework of their household. This ability actually represents the structure of the Javanese mental world. As previously mentioned by Geertz and Koentjaraningrat (1985) that Javanese women are known as gemi lan nastiti [6]. Gemi is always used together with nastiti, which means to be careful in taking on the responsibility of managing the household economy. In the Javanese world, women have the responsibility to manage finances and this is a symbol of women's authority and power. Gemi nastiti is a mental strategy used by Javanese women to fulfill their duties. Even though Javanese women are considered as konco wingking, women are in control as manager/ household executors.

\subsection{Javanese women always prioritize the balance of the two worlds}

In the Western view, the term macrocosm was appointed to indicate the universe which is the opposite of humans, while the microcosm is a small universe. Thus, the human body in the Western perspective is included in the microcosm. On the other hand, in the sense of Javanese culture, the human body is included in the macrocosm because it is controlled by lust and instincts. The microcosm in Javanese understanding is seen as a reality which is essentially inner, which gives birth to itself through concentric stages or circles. The highest life goal of the Javanese is the unity of self and God which can only be achieved through the conquest of the material world and the development of the inner world. Encounter with God can only be achieved through the subjugation of the ego.

The highest goal of Javanese spiritual life is the union of man with God (manunggaling kawula gusti). That highest goal is attained through the daily practice of living for inner growth. The highest stage of inner growth is when a person (Javanese woman) is convinced and aware that life must be in harmony and rhythm. The benchmark of the world for the Javanese is its pragmatic value which achieves a psychological state of calm, serenity, and balance. For Javanese women, if all domestic and public elements are embodied in a harmonious unity of experience, the elements are compatible with each other/no tension means that they have succeeded in achieving their goals.

Women have the same possibilities and potential as men to determine their position and create their social space in society. But women must set priorities to determine which areas they should occupy and when they should be in those areas. So, the meaning conveyed from the representation of the role of women in the painting Damar Kurung by Masmundari 
is to maintain a balance between household tasks and social tasks in society. The Javanese household as open space can be likened to a scale. On these scales, women only need to increase or decrease the load on one side to keep the scales balanced. The consequence is that all forms of conflict and resistance can be solved by viewing the household and the public sphere as two areas whose elements can circulate freely from one side to the other.

Women become Javanese women because they live according to their social consciousness. Women have an awareness that the Javanese world can only live if everyone does their job with the ability to measure the balance between the household and the public sphere. In everyday life, the relationship between men and women, between the household (domestic) and the social world (the public) is like a pair of shoes. Can't say that the left shoe is more important than the right shoe, or vice versa. Good or bad in this case is not determined by the two shoes, but is determined by the synchronization and movement of the two shoes. The existence of the household and the public sphere occupied by men and women confirms that they are different but complementary ideas.

\section{CONCLUSIONS}

From what was discussed earlier, it is clear that work in the public sphere and the household (domestic sphere) are not two opposing worlds. The inclusion of work activities for Javanese women in their daily lives does not keep them away from the cultural system without denying that these activities make women have to assume more responsibilities and have to manage their time better for all women's movements that are followed. The household has always been regarded as the central pillar of women's world, while work is a form of expanding the household's space.

In the Javanese world, working for Javanese women is neither a primary goal of earning money nor as an escape from domestic responsibilities to establish a separate and social workspace of their own. On the other hand, work actually increases and enriches her strength as a housewife. So the choice of Javanese women to work and have an income is one of the efforts to maintain the balance of the Javanese world.

The presence of women in the Javanese world becomes the main pillar both in the household and in society which ensures the harmony of the two worlds. The household is the center of the Javanese world and it is at the center that women are. Being on the axis means being in a stationary condition, not moving up and down or sideways. Silence and calm are a reflection of the inner attitude towards manunggaling kawula gusti which is the main goal of Javanese mysticism, including Javanese women.

The above conceptions show that Javanese women are not present and play their roles as other people, they still appear and carry out the roles offered by society with full social awareness even in the domestic sphere, while still being able to influence the public sphere through their roles in the household.

\section{REFERENCES}

[1] Budiman, Manneke, Bapak Rumah Tangga: Menciptakan Kesetaraan atau Membangun Mitos Baru?, Jurnal Perempuan, Vol 18 No. 1, Maret, 2013,pp. 79-92.

[2] Christianna, Aniendya, The Role of Damar Kurung Lantern as a Time Signal of Gresik Society, Jurnal Sosioteknologi ITB Vol 17, No 1. Institut Teknologi Bandung, 2018.

[3] Christianna, Aniendya, Javanese Women Hybridity: Postcolonial Study of Nyonya Muluk in Damar Kurung Paintings. IJCAS (International Journal of Creative and Arts Studies) , Institut Seni Indonesia, Yogyakarta.Vol 7 No 1, 2020.

[4] Fakih, Mansour, Analisis Gender dan Transformasi Sosial. Pustaka Pelajar Offset, Yogyakarta, 2007.

[5] Geertz, C., The Interpretation of Culture, Basic Books Inc, United States of America, 1983.

[6] Geertz, C., The Religion of Java, The University of Chicago Press, Chicago and London,1996.

[7] Handayani, Christina dan Ardhian Novianto, Kuasa Wanita Jawa, LkiS Yogyakarta, 2004.

[8] Imam Widodo, Dukut, dkk., Gresik Tempo Doeloe. Pemerintah Kabupaten Gresik, 2004.

[9] Indrakusuma, Danny, Masmundari Mutiara dari Tanah Pesisir, Penerbit Pustaka Pesisir, Surabaya, 2003.

[10] Koentjaraningrat. Javanese Culture, Institute of Southeast Asian Studies. Oxford University Press, Singapore, 1985. 
[11] Koeshandari, Ika Ismoerdijahwati, Damar Kurung dari Masa ke Masa, Dewan Kesenian Jawa Timur, Surabaya, 2009.

[12] Lombard, Dennis, Nusa Jawa Silang Budaya, Penerbit Gramedia Pustaka, Jakarta, 1990.

[13] Mustakim, Gresik Kajian Sejarah Sosial dan Ekonomi Maritim Abad ke-14 dan $18 \mathrm{M}$, Tim Pagan Press, Lamongan, 2019.

[14] Permanadeli, Risa, Dadi Wong Wadon: Representasi Sosial Perempuan Jawa di Era Modern. Pustaka Ifada, Yogyakarta, 2015.

[15] Tim Penyusun Buku Sejarah Hari Jadi Kota Gresik, Kota Gresik Sebuah Perspektif Sejarah dan Hari Jadi, Gresik: Pemerintah Kabupaten Daerah Tingak II Gresik, 1991.

[16] Zainuddin, Oemar, Kota Gresik 1816-1916 Sejarah Sosial Budaya dan Ekonomi, Ruas, Depok, 2010. 